\title{
FRANCIS BACON, JAN BAPTIST VAN HELMONT AND DEMETRIUS CANTEMIR. FAMILY RESEMBLANCES OF AUCTORITAS IN EARLY MODERN EUROPE
}

\author{
Sorin CIUTACU \\ West University of Timisoara, Romania \\ e-mail: sorinciutacu@gmail.com
}

\begin{abstract}
The present paper stakes out the destiny of certain ideas on scientific methods and epistemic and ontological representations that spread in $17^{\text {th }}$ century Europe like a cultural epidemiology of representations against a deist, theosophical, empiricist and occult maze-like background. Our intellectual history study evaluates the family resemblances of auctoritas of three polymaths: Francis Bacon, Jan Baptist Van Helmont and Demetrius Cantemir along the cultural corridors of knowledge. If Francis Bacon was a theoretical founder of doctrines and Jan Baptist Van Helmont was a complex experimenting spirit, Demetrius Cantemir was an able disseminator of philosophy in South Eastern Europe and a creative synthetic spirit bridging the Divan ideas of Western and Eastern minds caught up in the busy exchange of ideas of the Republic of Letters.

Keywords: Francis Bacon; Jan Baptist Van Helmont; Demetrius Cantemir; cultural epidemiology of representations; auctoritas; family resemblances; Early Modern Europe; polymaths; corridors of knowledge; Republic of Letters;
\end{abstract}

\section{Introduction}

The $17^{\text {th }}$ century stood for a transition period between an ontological outlook of vitalism that typified Renaissance thinking through to the early modern outlook of Francis Bacon, the founder of the scientific method to the mechanistic thinking put forward by Descartes and Newton. The present paper stakes out the destiny of certain ideas on scientific methods and epistemic and ontological representations that spread in $17^{\text {th }}$ century Europe like a cultural epidemiology of representations against a deist, theosophical, empiricist and occult maze-like background (see also Sperber, 1996).

Our intellectual history study evaluates the fuzzy family resemblances of three polymaths: Francis Bacon (1561-1626), the early modern philosopher, a holder of a breakthrough type of auctoritas in the history of science, Jan Baptist Van Helmont (1579-1644), a Flemish scientist, a contemporary polymath of Francis Bacon who develops Bacon's ideas on experiments and a Romanian prince and polymath, Demetrius Cantemir (1673-1723), who disseminates and reinterprets Van Helmont's ideas at the end of the $17^{\text {th }}$ century and at the beginning of the $18^{\text {th }}$ century. Our focus 
will be on Cantemir's role as a disseminator of auctoritas in Joannis Baptistae van Helmont Physices Universalis Doctrina and as a creative and re-evaluative philosopher in "Sacrosanctae Scientiae Indepingibilis Imago".

By auctoritas I understand the kind of authorship that grants a scholar prestige and influence of ideas over other scholars and the possibility for the ideas to be further expanded by those influenced.

The study sets out to ascertain some ideas in family resemblances clusters that represent the mainstay auctoritas in Francis Bacon's Novum Organum (1620), in Jan Baptist Van Helmont's paradigmatic doctrine from Ortus Medicinae (1648/ 1664 (the English translation)/1682/1683) and their transfer under the guise of fragmentation, reordering and re-interpretation into Cantemir's works from South-Eastern Europe.

By family resemblance I understand something close to what Ludwig Wittgenstein suggests in his Philosophical Investigations and namely the presence of a fuzzy degree of resemblance between the sets of overlapping ideas (seen as fibres of a thread) of the scholars in question and the absence of full similarity of the ideas expounded by them. „Something (that) runs through the whole thread (of ideas (our addition)- namely the continuous overlapping of those fibres" (Wittgenstein, 1953).

\section{Francis Bacon}

It was Sir Francis Bacon who laid the foundations of the scientific method. He expounded his ideas in Novum Organum (1620), or 'New Method', and was a reaction to Aristotle's method from Organon. (Hannam, 2017: 35). In Novum Organon, Francis threw out the frequently used Aristotelian view on science during the Middle Ages. His scientific method would be put to good use during the early years of the Royal Society founded in 1660 .

Francis Bacon's theories worked against the predecessors' doctrines like Aristotle's and Plato's and he also levelled criticism at Paracelsus' findings, although he embraced many of Paracelsus tenets throughout his writings. Bacon brings the array of Renaissance alchemists under fire as their methods hinge on occasional observations, and methodologically fall short of the experimental reproducibility of the researched natural effects.

In return, Bacon relished the findings of the Greek atomists and especially of Democritus. In building his ontology and theory of knowledge, Bacon chose Democritus' natural philosophy over Aristotelian teachings as they were recast into a scholastic mould.

Bacon found fault with Aristotle's theory of sundry sciences that missed out on building an overarching "meta-science" (philosophia prima) that should find its use in all the scientific pursuits. He does not entirely throw out Aristotle's works. Bacon dislikes the humanistic spin granted to his 
works because this spin brings syllogism and dialectics to the fore and resents the metaphysical tackling of natural philosophy as Bacon believes its forms to be framed as a pyramid making up ordo naturae itself.

Speaking of Aristotelian philosophers that could be a source to Bacon's thinking, we might bring up the case of Padua university professors and namely, the case of Jacopo Zabarella. This route may have acted as a corridor of knowledge feeding Bacon's speculative system drawing upon sundry sources which nourished his intellectual becoming: Democritus's atomism, Zabarella's Aristotelianism, Paracelsus, but also from contemporary scientists.

He rehashes Aristotle's outlook of science as knowledge of necessary causes. Bacon also dismisses Aristotle's logic on account of its metaphysical underpinning, and disproves the theory according to which the experience that reaches humans through their senses faithfully represents things as they are. Bacon also criticises Aristotle for imposing general and abstract concepts, which are unsuitable and unable to pinpoint things as they are. In exchange for the indicated shortcomings, Bacon sets up philosophia prima as a methodological meta-science for all scientific pursuits.

Bacon's corpuscular ontology finds semina rerum as a grounding principle that makes for the possibility of motion and reproduction of forms. These semina rerum have the solidity of fine particles which, in conjunction with air and fire, yield the animate or inanimate chains of being.

Speaking of the seminal scientific method, one can say it is an instance of inductive reasoning. Bacon's approach sets out the requirements for recording the accurate, systematic observations one needs in order to assert quality facts. Bacon recommends that one should fall back on induction, which he defines as one's ability to jump from a set of facts to one or more general theorems or axioms. He warns us about the limits beyond which the facts fall short of what they actually truly demonstrate.

Next Bacon recommends that one should proceed to collecting additional data or one should employ the extant data and the new theorems or axioms so that one can go on and formulate additional theorems or axioms. Bacon mentions negative and exceptional cases and data issued forth by experiments. The whole process should be resumed algorithmically so that one can lay down the sound foundations of knowledge, where this knowledge is buttressed by empirical data.

Bacon shows his cautionary wisdom in the Novum Organum by reminding us that one can come by this genuine and sound knowledge only by following the steps included in this method. He delineates himself from the old methods which were not rooted in facts but they hinged on erroneous deductions and metaphysical conjecture. If the old methods did still proceed 
from facts, they suffered from hasty generalisations from insufficient empirical data.

It is worth noticing that although Francis Bacon stood up for a highly rigorous, empirical, observational scientific method that ousted the old metaphysical conjecture method, Bacon remained a deeply religious man, who believed in God's creation. Deist Bacon underlines the fact that if man as a researcher comes to understand the essence of his work, he will succeed in comprehending the miracle of God's work and that he will be able to earn back the rightful knowledge man forfeited on the occasion of the original sin and will reach his God-given full potential.

To conclude the section on Francis Bacon we may define his leaning towards speculation as Bacon's awareness that his approach was an intermediate stepping stone in the scientific progress as if awaiting the later more sophisticated research hypotheses to prove or disprove the empirical theories set forth by him. Francis Bacon remains a man of his times as a trailblazer and also man ahead of his times through his cautionary and lucid insights.

\section{Jan Van Helmont}

The Flemish scholar Jan Baptist Van Helmont like his mentor, Paracelsus, illustrates this gradual progress from vitalism to mechanicism mingled with insights into corpuscularianism, physicalism and naturalism much like Francis Bacon uses the auctoritas of Paracelsus. Van Helmont shares the interest in experiments and empirical data collection with Francis Bacon and follows his principles in broad lines. $\mathrm{He}$ is an alchemist, philosopher, natural scientist and physician and his main works are included in Ortus Medicinae.

Van Helmont was much under the spell of the auctoritas of Paracelsus as Francis Bacon was as he looked upon the universe "as an organism in which matter was configured by a development of forces". Even though Van Helmont endorsed Paracelsus' theory, he still stopped short of taking over the 3 fundamental elements of Paracelsian matter: tria prima (mercury, salt and sulphur) (see also Ducheyne, 2006).

In exchange, Van Helmont's ontology posits water as a primordial omnipresent element in each natural combination. The Flemish scientist busied himself with pyrothechnia and is credited with having coined the word gas derived from Greek chaos.

On the one hand Van Helmont is eulogised for various discoveries and for his interest in empirical observation and experimentation in general. On the other hand, Van Helmont is often described as an alchemist swayed by mysticism, who levelled criticism at human reason (mens rationalis), Mathematics, and syllogistic reasoning. He claimed, for example, that we 
should not have a rational mind, but rather an intellectual one. According to Van Helmont, almost like with Bacon, only the soul could provide a deeper understanding of nature. Animal reason (mens sensitiva) can only come to reach the external appearance of things: the signatum, but not the essence hidden within it (de zegelaer). Insight works by means of forms, figures, and examples (gedaenten, figueren, en voorbeelden) rather than by means of deductive reasoning. (see also Ducheyne, 2006)

Dreams were equally important to Van Helmont. In the introduction to Ortus Medicinae (1648), Van Helmont spoke of a fervently mystic dream he had: he found himself in an empty bubble the diameter of which reached from the centre of the earth to the heavens above. From this allegorically religious dream, Van Helmont understands that in Jesus Christ we live, move, and guide our being. Van Helmont also criticises the restrictiveness of Mathematics: Mathematics studies only the quantitative aspects of things, not their inner qualities (Ducheyne, 2006).

Proper science deals not only with the quantity of things, but also with their quality. Mathematics places entities under the praedicamentum quantitatis: it does not succeed in thrusting to the essence of things (wesentheyt) (see also Ducheyne, 2006).Van Helmont criticises the Aristotelians saying that they disregarded the inner principles, the semina, of things and brought down things to the level of an artefact, much like Bacon does. According to Van Helmont, Nature does not busy itself with external signs, but only with causes.

Van Helmont sets up an ontological principle called the archeus. He defines archeus as "aura vitalis seminum, vitae directrix", "the conjoyning of the vitall air, as of the matter, with the seminal likeness, which is the more inward spiritual kernel, containing the fruitfulness of the Seed; but the visible Seed is only the husk of this."(Van Helmont,1664). We find the same semina concept drawing on the Greek atomists as with Bacon.

Van Helmont posits the sensitive soul above the archeus and defines it as the husk or shell of the immortal mind. Van Helmont claims that before the Fall the archeus hearkened to the immortal mind and was directly steered by it, but at the Fall men also were gifted with the sensitive soul, but with it they forfeited their immortality, as when it dies, the immortal mind can no longer abide in the body.

In addition to the archeus, van Helmont believed in other agentive entities that could be likened to the archeus, but these entities were not always clearly set off from the archeus. Having these in mind, Van Helmont coined the term blas (motion), defined as the „vis motus tam alterivi quam localis" („twofold motion, to wit, locall, and alterative"), that is, natural motion and motion that can be altered or voluntary motion. The concept 
of blas was of various types: e.g. blas humanum (blas of humans), blas of stars and blas meteoron (blas of meteors); of meteors he claims that „constare gas materiâ et blas efficiente” („Meteors do consist of their matter Gas, and their efficient cause Blas, as well the Motive, as the altering", see Van Helmont, 1664 apud Ducheyne, 2006).

In Van Helmont's works we find experiments classified as follows (Ducheyne, 2006):

1) experimentum: technical or medical procedures that are rationally not fully warranted and for which there is no other evidence of their worth except for the results they yield;

2) mechanica probatio ("hands-on demonstration"): evidence thrown up by the lab work; and,

3) quaerere per ignem ("questioning by fire"): Paracelsian methods of chemical fire analysis.

According to Halleaux (1983), Van Helmont demonstrates his experimental tenets by delving into the mechanisms of four experiments: the thermoscope experiment, the transmutation experiment (as an alchemist), the ice experiment and the willow-tree experiment.

Jan Baptist Van Helmont is an obvious supporter of experimental research exactly like Bacon. He anticipated the rise of present-day procedures such as: quantification, control, theory-guided practice, practice informed theory, replication and reproducibility. (see also Ducheyne, 2006)

As a physicist, Van Helmont believed in the weight conservation law (pondus) by claiming that water as an indestructible element rarefied or condensed by the semina (see this concept with Bacon) is omnipresent (see Ducheyne, 2006). As a chemist, the Flemish scientist claims that chemical reactions do not affect the weight of the substances involved. Philosophically, he throws in an ontological conclusion that everything desires to remain itself as long as possible.

\section{Demetrius Cantemir}

The Romanian Prince, a Reichsfuerst of the Holy Roman Empire, Demetrius Cantemir was a scholar of the Republic of Letters (Boucher, 2006: 8) of the Early Enlightenment (1680-1730). Demetrius Cantemir proved himself a truly European polymath encapsulating the highest expression of Western and Eastern lore, a member of the Prussian Academy and a pen friend of G.W. Leibniz. Cantemir came to learn of the posthumous writings of Jan Baptist Van Helmont through different corridors of knowledge.

The main corridors of knowledge envisage the tide of scholars from Constatinople, who returned home to the Greek Academy after studying at 
the University of Padua. Thus Padua, also visited by Jan Baptist Van Helmont, and Constantinople, where Cantemir spent several years, stand out as important and long-lasting hubs of knowledge. It is at Padua that one of Bacon's Aristotelian source of inspiration, Jacopo Zabarella lived and taught in the $16^{\text {th }}$ century. These hubs of knowledge connected by corridors of knowledge are materialised through an active exchange of books, manuscripts and ideas debated by scholars in close contact or who maintain a fertile correspondence on scientific matters.

It is also in Constantinople at this Greek Academy of the Patriarchate that Cantemir came in touch with different philosophical ideas and natural sciences discourses that make for a well thought through kind of paradigmatic auctoritas that witnesses the fragmentation, and reordering of the springs of knowledge typical of early modern Europe. In Constantinople, Cantemir attended the Academy of the Ecumenical Patriarchate from Fener, a district of the city, where he was taught by scholars like Meletios de Arta and Jacobos Manos (see Lemny, 2010). These corridors of knowledge are also corridors of auctoritas transfer and exchange and typify the network concept of the Republic of Letters.

Cantemir writes a book while in Constantinople (in 1700-1702) praising and directly making Van Helmont's auctoritas known through his work on Joannis Baptistae van Helmont Physices Universalis Doctrina (see also Cantemir, 1872 and 2015). Debus (2002: 311-312) mentions the fact that Demetrius Cantemir wrote a biography of Van Helmont and paraphrased his work in Joannis Baptistae Van Helmont physices universalis doctrinae et christianae fidei congrua et necessaria philosophia. Debus adds the remark that the work of Cantemir includes only a selection of „Ortus Medicinae”, but he admits that Demetrius Cantemir has the merit of disseminating the auctoritas of Van Helmont throughout Eastern Europe.

Cantemir jotted down his comments while he perused Jan Baptist Van Helmont's Opera Omnia published by Frans Mercurius Van Helmont in Frankfurt am Main in 1682 and in Amsterdam in 1693, as we mentioned earlier in the study. As a consequence of his enthusiasm regarding Van Helmont's scientific and philosophical achievement, Cantemir utters his praise for Van Helmont's physics of creation and iatrochemistry.

Demetrius Cantemir was so gripped by Van Helmont's ideas that he copied out the entire 820 page manuscript of the treatise on doctrina universalis. Cantemir wrote the above mentioned text in Latin and Romanian called Praise to the author and to the virtue of his scholarship and a foreword in Latin Lectori amico. Both were meant to be published. The edition features the portraits of Van Helmont father \& son drawn in fine ink by Cantemir himself after the 1682 engravings (see also Lemny, 2010). 
This option for Van Helmont's auctoritas evinced by Cantemir might have been made under the influence of Cantemir's professor in Jassy, Jeremiah Kakavelas (who was a disciple of Teophilos Corydaleos, a scholar who studied at the Padua University) and of his above mentioned professors in Istanbul: Iacobos Manos and Meletios de Arta, who had strong connections with the Padua University. Cantemir was not fully conversant with all the Early Modern European philosophy in full swing at the end of the $17^{\text {th }}$ century and he chose Van Helmont's system recommended by his professors as a key meant to help him unlock the riddles of his philosophical queries.

Cantemir also leans on Van Helmont's teachings in books like: The Divan (1698), which possibly draws on Van Helmont's Venatio Scientiarum and in Sacrosanctae Scientiae Indepingibilis Imago (1700) (see Alexandrescu, 2013) which reinterprets Van Helmont's cosmogonic ideas on the genesis from the Bible. Bădărău (1964) suggests another source for The Divan and namely Dioptra (The Mirror) by Philippus Solitarius (Monotropos), a work written in the $11^{\text {th }}$ century.

In Historia Incrementorum atque Decrementorum Aulae Othomanicae (1714-1716) and in Monarchiarum Physica Examinatio Cantemir employs the cyclical "law" of history within a biologist framework and deems human societies to be like living beings subject to the universal law of wax and wane as history is tantamount to continuous becoming. Cantemir however discards the use of "archeus" in his sociological discourse unlike Van Helmont. (see Bădărau, 1964, 394-410).

My conjecture says that one possible corridor of knowledge, albeit a later secondary one, takes shape through the action of G.W. Leibniz, who is also a friend of Jan Baptist Van Helmont's son, Franciscus Mercurius Van Helmont, who, an alchemist himself, publishes his father's complete works in Amsterdam, in 1683 after the republishing of OPERA OMNIA in Frankfurt am Main, in 1682. But this corridor of knowledge, Amsterdam-Berlin-St Petersburg, chronologically can only come up for discussion as a reinforcing source for a later period, after Cantemir becomes Peter the Great's advisor, that is after 1711 .

Both scholars see God as the world's maker and admit that truth is afforded to man directly through divine enlightenment. Cantemir manages to strike a compromise reconciling reason with revelation. Van Helmont's doctrine represents his utter split with the medieval, scholastic thought by upholding the Christian doctrine against heathen Aristotelianism. Bacon, too, remains an upholder of the laws of Divinity.

Van Helmont believes that this divine enlightenment runs counter to reason and its logic. So does Cantemir, who also suggests that man is left with logic and reason after the loss of the sacred science. Logic and reason 
can steer man towards the path of knowledge. Therefore this split is not successful with Cantemir as he still preserves the double truth theory and, consequently, the idea of a holy science, which he previously rejects.

We agree with Bădărau (1964) that Van Helmont's dialectics held a precarious status whereas Cantemir deemed it essential for the comprehension of logic, history of philosophy and causation theory.

Demetrius Cantemir pens" "Sacrosanctae Scientiae Indepingibilis Imago by falling back on a host of vivid metaphors to make his philosophical outlook as expressive and appealing to readers as possible (Lemny, 2010).

The book sets out to counter Aristotelian thinking and Scholastics. Cantemir employs philosophy to justify the Christian lore by adducing arguments from the philosophy of nature, also bringing in moral, religious and epistemic issues.

The book "Sacrosanctae Scientiae Indepingibilis Imago", which appeared at the watershed of centuries (1700), has the ambition to embed Physics within a deist framework, exactly as Francis Bacon had done before, finding the common ground between science and religion, by bridging the gap between science-based determinism and medieval metaphysics. Being a polymath, Demetrius Cantemir craved to know the esoteric underpinnings of sciences.

The structure of this work includes six books. Book one unfolds a didactic meditation on the relation between Philosophy and Theology under the guise of a dialogue aimed at revealing some occult lore to a young disciple. Book two, which has 33 chapters, shows forth the influence of Van Helmont's occult doctrine regarding the Biblical Genesis as Cantemir spells out a theory of cosmogony using Van Helmont's physical principles. Book three provides explanations of natural phenomena like rainbows, earthquakes, volcanoes, etc. Book four resumes the motif of the meditation on the lapse of time in an allegorical way. Book five affords us an insight into the philosophy of universal life. Book six is a philosophical plea for the free will and it sketches out a theodicy somewhat in a Leibniz-like manner.

Thus in "Sacrosanctae Scientiae Indepingibilis Imago" Cantemir imagines himself as a painter when the author sets about mooting the knowledge issue and of its representation in the craft of painting. The allusion to Horace's creed: "ut pictura poesis" is obvious here trying to drive the idea home that a comparison between the painters' freedom and the poets' freedom is possible wherein both sides feel free to attempt at crafting objects according to their imagination.

The allegory of Truth includes the scene where Truth as an object to be represented is bidden to sit for the painter as a model. The sitter as Truth is described as an elderly wise man: the Father of Time. The painter tries hard 
to be painstakingly accurate when drawing Truth's portrait, which tract of descriptive discourse allows the painter to ponder over the limits of his art.

Another esoteric and epistemic metaphor stands out in the recounting of the scene where the painter, after he completes his work, hands a mirror to the Father of Time for him to behold his own countenance and compare it to the painting. This enigmatic mirror spells out the meditation on man's powers and limits to know Truth and to represent it.

Here, Cantemir dismisses the ancient philosophers' tenet that claims that one can come by knowledge through reason, but here Cantemir is also at odds with Bacon and the host of English empiricists to follow in the $18^{\text {th }}$ century, who claim that knowledge is first mediated by senses, however faithfully this might come about.

Following Van Helmont and like Bacon, under the guise of a family resemblance Cantemir sees the foundations of creation as being made up of elements, ferments and archei, and therefore he rejects the primum movens idea of Aristotle, which sets everything else in motion, while God resides not only in nature, but also above nature, setting everything in motion in a praeternatural and free manner. Cantemir's Physics posits the existence of a cosmic matter that was in continuous fermentation, preserved life, admitted of divina revelatio. The Romanian polymath believed in divine enlightenment and in hidden meanings to be wrestled from nature. This ties in well with Cantemir's attempt at squaring science based-determinism with deism like Bacon and Newton did. In another work, in Compendiolum, Cantemir wavers and there he changes his attitude towards Aristotle and accepts his tenets.

The process of creation goes on unimpeded after the act of divine creation is finished, whereby Cantemir means that God's intervention occurred in the first phase of creation as an immediate and praeternatural force and regarding the ensuing natural phenomena of the order of nature God withdraws and becomes a sort of Deus otiosus and thus saving only the praeternatural phenomena for himself. Another family resemblance is apparent when Cantemir follows Van Helmont directly and Bacon (indirectly) as he claims that nature is God's order through which a thing is what it is and does what it has been ordered to do (see Cantemir, 2015).

The order of nature is an original concept of Cantemir's, which does not draw on Van Helmont's system, whereby Cantemir tries to feature a deterministic link between God and nature in a systematic way although the order of nature (ordo naturae) is a concept that shows up with Bacon bespeaking its Aristotelian aftermath and might constitute another family resemblance.

Sacrosancta scientiae indepingibilis imago has the virtue of being the first philosophical book ever written by a Romanian author and is an attempt 
at including ontology, cosmogony, logic and morality by drawing upon the theosophical system of Jan Baptist Van Helmont in order to counter scholastic and Aristotelian thinking. It is the creative and re-evaluative work of an ambitious polymath trying to square scientific ratio with religious revelatio.

\section{Conclusions}

Cantemir's works stand on their own merits but also on the shoulders of other giants of the 17th century, the deist and theosophical empiricists from Early Modern Europe. All the three polymaths, Bacon, Van Helmont and Cantemir developed their theories by taking a stance against Aristotle's teachings and their works grew out of their conscious break with the medieval, scholastic thinking resting on Aristotelian tenets. They all admitted to God's existence and attempted at reconciling ratio et revelatio to different degrees and under different epistemic circumstances. They all busied themselves with ontology, logic, cosmogony and the empirical theory of knowledge and in doing so they yielded family resemblances of auctoritas among their seminal ideas for us to pick out.

If Francis Bacon was a theoretical founder of empirical doctrines and a philosopher (even if he was not quite an alchemist) and Jan Baptist Van Helmont was a iatrochemist, alchemist and a complex experimenting spirit, Demetrius Cantemir was an able disseminator of philosophy in South Eastern Europe and a creative synthetic spirit bridging the Divan ideas of Western and Eastern minds caught up in the busy cultural epidemiology of representations of the Republic of Letters of Early Modern Europe.

\section{References:}

Aristotle (1963). Metaphysica. In The Works of Aristotle. 8 vols. 2nd ed. Oxford: Clarendon Press.

Alexandrescu, V. (2003). "Un manuscrit inédit et inconnu de Démètre Cantemir. L'Epître dédicatoire du traité Sacro-sanctae scientiae indepingibilis imagol "An unpublished and unknown manuscript by Demetrius Cantemir. The dedication epistle of the treatise Sacro-sanctae scientiae indepingibilis imago. In ARCHAEVS. Etudes d'histoire des religions, VII (2003) 3-4, pp. 245-269. București.

Bacon, F. (2000). Novum Organum, Cambridge: Cambridge University Press.

Bădărău, D. (1964). Filozofia lui Dimitrie Cantemir/Demetrius Cantemir's Philosophy. București: Editura Academiei Române

Bouchard, J. (2006). Nicolae Mavrocordat. Domn și cărturar al iluminismului timpuriu/Nicholas Mavrocordat. Prince and Scholar of Enlightenment (16801730). București: Editura Omonia. 
Cantemir, D. (1872). Operele Principelui D. Cantemir/The Works of Demetrius Cantemir. București: Editura Academiei Române.

Cantemir, D. (2015). Metafizica/ Metaphysics. București: Editura Acum Info.

Debus, A.G. (2002). The Chemical Philosophy: Paracelsian Science and Medicine in the Sixteenth and Seventeenth Centuries. Dover: Courier Dover Publications.

Ducheyne, S. (2006). Joan Baptista Van Helmont and the Question of Experimental Modernism. Gent. Abstracts of the 6th Int. Conf. for the History of Chemistry. pp.18-18

Halleux, R., (1983). Helmontiana/ Helmontiana. Mededelingen van de Koninklijke Academie voor Wetenschappen, Letteren en Schone Kunsten van Belgie*/ "Papers of the Royal Academy for Sciences, Letters and Fine Arts of Belgium". Academia Analecta, Klasse der Wetenschappen, 45 (3). Brussels. pp. 33-63.

Hannam, J. (2017). God's Philosophers. London: Icon Books.

Lemny, Ș. (2010). Cantemireștii. Aventura europeană a unei familii princiare din secolul al XVIII-lea/ The Cantemirs. The European Adventure of a Princely Family. Iași: Editura Polirom.

Ploeșteanu, G. (2007). Receptarea operei si a personalității lui Dimitrie Cantemir în Europal The Reception of Demetrius Cantemir's Works and Personality. Târgu Mureș: Editura Veritas.

Redgrove, H.S., Redgrove, I.M.L. (1922). Joannes Baptista Van Helmont. London: William Rider \& Sons.

Sperber, D. (1996). Explaining Culture. A Naturalistic Approach. Oxford: Blackwell.

Van Helmont, J.B.(1664). Works, Containing His Most Excellent Philosophy, Chirgury, Physick, Anatomy. Wherein The Philosophy of Schools is Examined, their Errors Refuted and the Whole Body of Physick REFORMED and RECTIFIED. Being a New Rise and Progresse for PHILOSOPHY and MEDICINE, for the Cure of Diseases and the Lengthening of Life. London.

Wittgenstein, L. (1953). Philosophical Investigations. Cambridge: Cambridge University Press. 